Floresta e Ambiente 2020; 27(2): e20171149

https://doi.org/10.1590/2179-8087.114917

ISSN 2179-8087 (online)

\title{
Soil Carbon Fractions in Rubber Trees, Pasture, and Secondary Forest Areas
}

Anderson Ribeiro Diniz ${ }^{1}$ (D) 0000-0002-8471-5120

Roni Fernandes Guareschi ${ }^{1}$ (D) 0000-0002-4122-9405

Marcos Gervasio Pereira ${ }^{1}$ (D) 0000-0002-1402-3612

Douglath Alves Corrêa Fernandes ${ }^{1}$ (D) 0000-0003-2920-7630

Fabiano Carvalho Balieiro ${ }^{2}$ (D) 0000-0002-0229-6672

Eduardo Vinícius da Silva ${ }^{1}$ (D) 0000-0002-1115-0624

Marisa de Cássia Piccolo ${ }^{3}$ (D) 0000-0003-2163-5630

\begin{abstract}
This study quantify the total organic carbon content, light fraction organic matter (LFOM), and soil organic matter fractions (from chemical and physical fractionations) in four different cultivation areas: 1 and 2) rubber tree clonal plantations (FX 3864 and IAN 873); 3) a pasture; and 4) a secondary forest. The research was carried out using soil samples from clonal plantations of eight-year-old rubber trees, located in the coastal plain (Tabuleiros Costeiros) of the state of Rio de Janeiro. The difference in the management of the rubber tree clone area promoted improvements in the soil quality, as it increased the carbon contents of the granulometric fractions, LFOM, and humic substances from the IAN 873 clone area. Both rubber tree areas evaluated presented higher mineral-associated organic carbon levels and humic substances than did the pasture area, reinforcing the reforestation potential of areas with degraded pastures through hevea culture.
\end{abstract}

Keywords: Hevea brasiliensis, organic matter, soil carbon fractionation.

\section{INTRODUCTION AND OBJECTIVES}

Currently, Brazil accounts for approximately $1 \%$ of the world's natural rubber production. Despite this small contribution, the rubber sector has great importance in Brazil, as evidenced by the presence of several rubber processing industries, especially in pneumatics, and a demand that is still far from being met by domestic production (Barreto et al., 2016; Gonçalves et al., 2010; Rodrigues \& Costa, 2009).

When handled properly, forest management systems can maintain or even increase the organic carbon fraction in the soil, thus contributing to the maintenance of the soil's productive capacity and mitigating the increase of atmospheric $\mathrm{CO}_{2}$ (Siqueira Neto et al., 2011). According to Diniz et al. (2015) and Portugal et al. (2008), cultivated rubber trees may store similar or higher amounts of carbon in the soil than natural and planted forests do, making them a good alternative for increasing the carbon levels in degraded pastures areas. Studies in the literature indicate that rubber trees have a higher capacity to produce biomass and to store carbon in their biomass and in the soil, with values varying from 50 to $114 \mathrm{Mg} \mathrm{ha}^{-1}$ of carbon in biomass, and 60.1 to $181.07 \mathrm{Mg} \mathrm{ha}^{-1}$ of carbon in the soil (Cotta et al., 2008; De Blécourt et al., 2013; Diniz et al., 2015; Fernandes et al., 2007; Maggiotto et al., 2014; Salgado, 2016; Wauters et al., 2008). The variation in carbon values found is due to the differences in the methodologies applied, as well as to variations in land management, climate conditions, and age of plants (Salgado, 2016).

However, beyond the importance of analyzing the total carbon amount and quality of the soil, other variables related to soil organic matter (SOM) stand out, including the light fraction organic matter (LFOM) and the SOM fractions obtained by chemical and physical fractionations (Diniz et al., 2015). However, there are few and/or scanty reports in the literature that have analyzed these variables together in areas of rubber tree cultivation and in adjacent areas with

\footnotetext{
${ }^{1}$ Universidade Federal Rural do Rio de Janeiro (UFRRJ), Seropédica, RJ, Brasil

${ }^{2}$ Centro Nacional de Pesquisa de Solos (Embrapa Solos), Rio de Janeiro, RJ, Brasil

${ }^{3}$ Centro Nacional de Energia na Agricultura (Cena), Piracicaba, SP, Brasil
} 
other vegetation (e.g., native grasslands and forests) that can be used as a reference (Diniz et al., 2015).

The LFOM is the fraction of light organic matter that increases the carbon content in the soil and improves it through nutrient cycling, in addition to responding very quickly to soil management (Portugal et al., 2008; Rangel et al., 2008). Diniz et al. (2015) studied the SOM dynamics in areas with various rubber tree clones. They found the highest LFOM levels in an area planted with the MDX 624 clone, which was attributed to the higher amount of litter that this clone deposited on the ground and the lower carbon-to-nitrogen $(\mathrm{C} / \mathrm{N})$ ratio of its residues. Similarly, Portugal et al. (2008) assessed the dynamics of organic matter in the Latossolo Vermelho-Amarelo Distrófico (Oxisol) in areas with rubber tree plantations, citrus orchards, pastures, and secondary forests. They also found that rubber trees were more efficient at increasing the levels of organic matter in the soil, probably due to their higher contribution of organic residues to the soil.

As for the carbon from humic substances - viz., from fulvic acid (C-FAF), humic acid (C-HAF), and humin (C-HUM) -, the interactions of these fractions with soil minerals influence the dynamics of carbon by favoring its maintenance and storage in the soil (Santos et al., 2013). By studying the dynamics of these fractions in areas with different rubber tree clones, Diniz et al. (2015) confirmed that there were differences between the clones studied, which were related to the quantity and quality of the organic material in the soil. In other words, in areas with a higher supply of carbon (via roots and shoots), and lower $\mathrm{C} / \mathrm{N}$ ratio, there is more formation of C-FAF.

Furthermore, in areas with clones that generate organic residue with a higher $\mathrm{C} / \mathrm{N}$ ratio, there is a predominance of more recalcitrant fractions, such as C-HAF and C-HUM. Portugal et al. (2008) also found higher C-FAF contents in the rubber tree plantation system than in the pastures and citrus orchard studied, due likely to a higher input of organic residue and LFOM that are generated in this system. According to the authors, this result indicates that rubber tree plantation systems have the potential to increase or maintain carbon levels in the soil, whereas pasture systems with low organic input reduce the soil carbon content.

Finally, it is worthwhile to look at the particle size fractionation of SOM, through which the particulate organic carbon (POC) and mineral-associated organic carbon (MOC) are quantified, and which has been used to evaluate the SOM dynamics of rubber tree areas (Diniz et al., 2015). Analyzing such fractions in areas with different rubber tree clones, Diniz et al. (2015) found similar levels of carbon content in the POC and MOC fractions for different rubber clones. They correlated these results to the short planting period for rubber trees and the similarity between the $\mathrm{C} / \mathrm{N}$ ratio and litter stock. The current study also showed the superiority of MOC over POC, due to the short planting time of the crop as well as environmental and soil conditions that favor the rapid decomposition of POC.

The objective of the current study was to quantify the total organic carbon (TOC) content, LFOM, and organic matter fractions (from chemical and physical fractionations) in the soils of two rubber tree clonal plantations (FX 3864 and IAN 873), a pasture, and a secondary forest.

\section{MATERIALS AND METHODS}

The study was conducted in areas of two rubber tree clonal plantations, a secondary forest, and a pasture in the municipality of Silva Jardim, located in the Coastal Lowlands region of the state of Rio de Janeiro, Brazil. The study area is located at $22^{\circ} 39^{\prime} 3^{\prime \prime} \mathrm{S}$ latitude and $42^{\circ} 23^{\prime} 30^{\prime \prime} \mathrm{W}$ longitude (Figure 1).

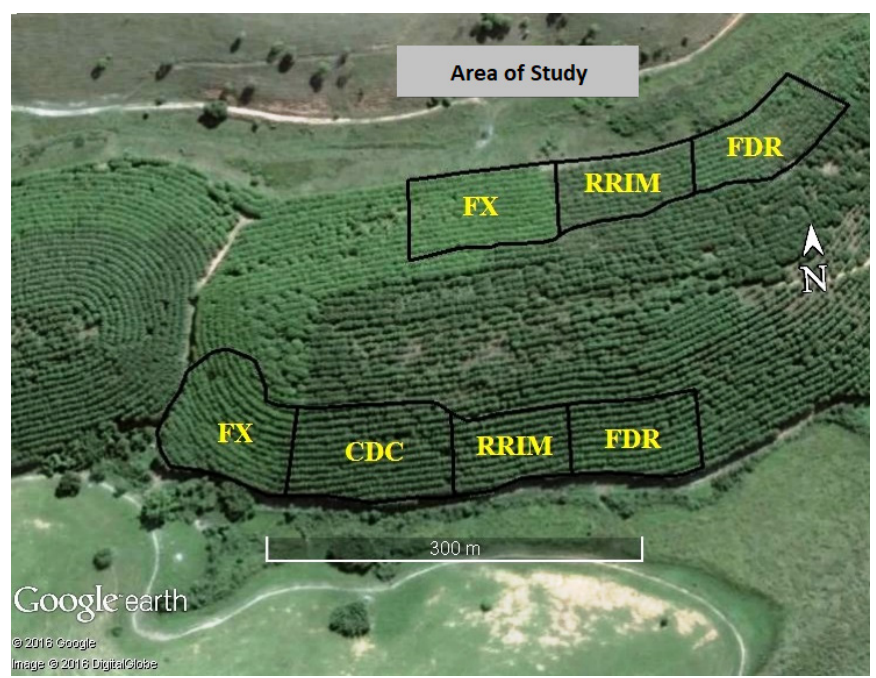

Figure 1. Division of rubber tree clones at local of study, Silva Jardim, Rio de Janeiro, Brazil. Source: Google Earth (2016). 
The soil was classified as Argissolo Amarelo Distrófico (Ultisol). In this study region, the soil source materials are the sediments of the "Barreiras" geological formation, varying in texture from sandy to clay. According to the Köppen climate classification system, the regional climate is Cwa type (i.e., tropical humid), with an annual average temperature of $23{ }^{\circ} \mathrm{C}$ and average annual rainfall of $1,500 \mathrm{~mm}$. The mean values of total rainfall, maximum temperature, minimum temperature, and average temperature for 2012 and 2013 (time period of data collection).

During the mid-1980s (ca. 28 years ago), a time period that saw the beginning of incentives for rubber tree cultivation in the state of Rio de Janeiro, two rubber tree clones were planted (IAN 873 and FX 3864) for latex production on the Pedacinho do Céu property ( $22^{\circ} 40^{\prime} 22.11^{\prime \prime}$ S; $42^{\circ} 25^{\prime} 55.53^{\prime \prime}$ W) in Silva Jardim. The property has four hectares of planted rubber trees: two hectares with the FX 3864 clone and other two with the IAN 873 clone, which have been in use for about eight years. The area where the FX 3864 clones are planted has an average slope of $21 \%$. During the year, the area is mowed two or three times, with the organic residue left on the soil. The area where the IAN 873 clones are planted has a steeper average slope of about $37 \%$, so it is mowed only once a year, along the planting line. The spacing used was $3 \mathrm{~m}$ between plants and $7 \mathrm{~m}$ between planting lines, for a density of 500 plants per hectare. There is no record of fertilizer use at the time of planting, and there have been no cover fertilizers used since the planting of the rubber trees.

In addition to these two rubber tree plantation areas, two other areas close to the clones were selected: a secondary forest of unknown age, and a pasture that was planted about 16 years ago and consists primarily of Urochloa sp. grass as well as some donkey tail grass (Andropogon bicornis L.) and thatch (Imperata brasiliensis). The pasture area is located at the top of a hill (a plateau) and is a grazing area for cattle herds during the year. When the pasture was planted, liming and fertilization with NPK were carried out, but there is no record of the input amounts applied.

In each area, plant material deposited on the ground was collected with the aid of a metal jig with an area equal to $0.0625 \mathrm{~m}^{2}$. Samples were collected only once, in January 2013. Three simple samples were randomly collected to form a composite, and 10 samples of litter were also collected.

The samples were kept in paper bags and stored in a greenhouse with controlled ventilation, at a temperature of $65^{\circ} \mathrm{C}$, for $48 \mathrm{~h}$. After this period, the samples were weighed to determine their dry mass. From these data, the dry mass of plant litter on the soil surface per hectare was determined. Subsequently, the litter stock was quantified as follows (Equation 1):

$$
\begin{gathered}
\text { Stock }\left(\mathrm{Mg} \mathrm{ha}^{-1}\right)= \\
{\left[\left(\text { weight of material, in } \mathrm{Mg} / \text { jig area, in ha }{ }^{-1}\right)\right](1)}
\end{gathered}
$$

Samples for determining the total organic carbon (TOC) content were collected from small trenches of $0-5$ and $5-10 \mathrm{~cm}$ in depth. Three simple samples were collected to compose each composite. In total, 10 composite samples were collected at each study area. The TOC content was determined according to the method described by Yeomans \& Bremner (1988).

Granulometric and chemical fractionation methods were applied to fractionate the organic matter in the soil, using the same trench samples used to determine the TOC content. The LFOM was determined according to previously described methods (Anderson \& Ingram, 1989). Granulometric fractionation was performed according to the method described by Cambardella \& Elliot (1992), whereas the chemical fractionation was carried out using a differential solubility technique established by the International Humic Substances Society, as adapted and presented by Benites et al. (2003).

The results were subjected to the Lilliefors test for normal distribution analysis of errors, and Cochran's test for homogeneity of variance of errors. Given the assumptions of normality and homogeneity, mean values were compared by Tukey's test at $5 \%$ probability $(p<0.05)$, R Core Team software.

\section{RESULTS AND DISCUSSION}

There were statistically significant differences in the litter stock levels among the study sites, as shown in Table 1. The forest area had the greatest biomass, due to its higher density of individuals, the greater size of its plants, and its more advanced age, all of which led to a greater deposition of organic material on the ground in comparison with the other areas.

\begin{tabular}{|ccc|}
$\begin{array}{c}\text { Table 1. Stock and C/N ratio of litter in areas with different soil uses. } \\
\text { Areas }\end{array}$ & Stock $\left(\mathbf{M g ~ h a}^{-1}\right)$ & $\mathbf{C} / \mathbf{N}$ Ratio \\
\hline IAN 873 & $2.0 \mathrm{c}$ & $23.3 \mathrm{~b}$ \\
FX 3864 & $2.2 \mathrm{c}$ & $22.7 \mathrm{~b}$ \\
FOREST & $6.3 \mathrm{a}$ & $21.9 \mathrm{~b}$ \\
PASTURE & $3.4 \mathrm{bc}$ & $47.9 \mathrm{a}$ \\
\hline CV\% & 23.0 & 12.5 \\
\hline
\end{tabular}

Values followed by the same letter in the column do not differ according to Tukey's test at 5\% probability. CV\%: coefficient of variation.

The pasture area had 53.5\% more litter than did the rubber tree plantation areas. This is due to the intense process of pasture biomass renewal and its higher $\mathrm{C} / \mathrm{N}$ ratio, which leads to a constant deposition of plant material on the soil that is more resistant to decomposition. Grasses contribute relatively with large amounts of biomass and high $\mathrm{C} / \mathrm{N}$ ratio, 
which can increase the persistence of soil cover (Perin et al., 2004) and lead to increased litter stocks.

Another aspect that should be considered is the time that the samples of litter stock were taken (January). At this time of year in the Coastal Lowlands region, the rubber tree clones have already been through the process of leaf fall that occurs in August and September. Thus, the leaves that make up the canopy are fully formed and mature, and are not in the senescence process that would contribute to significant additions to the litter stock. Moreover, the low litter stocks may also have resulted from the location of the study area (Coastal Lowlands), which has high temperatures and high annual rainfall (about 1,500 $\mathrm{mm}$ ) throughout the year, contributing to a faster rate of litter decomposition.

Litter production can be influenced by several biotic and abiotic factors throughout the year, including the type of vegetation, the stage of succession, whether a tree is deciduous, relief, temperature, availability of light, and age, among others.

Regarding rubber tree cultivation, there is a dearth of studies that have quantified litter stocks in plantations. In Brazil, one study by Kindel et al. (2006) quantified the litter stock of a forest in a mining area (Zona da Mata Mineira) with two 15-year-old clones, IAN 873 and RRIM 600; the clone areas were found to have 1.0 and $1.4 \mathrm{Mg} \mathrm{ha}^{-1}$ litter, respectively. A similar litter stock pattern was found by Murbach et al. (2003) at a 15-year-old rubber tree plantation in Rio Claro, São Paulo, where $1.7 \mathrm{Mg} \mathrm{ha}^{-1}$ of litter was reported. The litter stock values found in Silva Jardim are similar to those found in Zona da Mata Mineira and in Rio Claro, indicating a similarity of stock levels for the rubber tree crop.

Both the $0-5-\mathrm{cm}$ and $5-10-\mathrm{cm}$ layers of the forest area presented significantly higher carbon levels than did the other areas evaluated. The greater deposition of litter contributed to a high litter stock on the soil (Table 1), resulting in a higher input of organic matter (Table 2). Similarly, higher carbon stocks in the topsoil have previously been found in areas of a seasonal forest than in pasture areas, due to increased deposition of organic material on the soil (Guareschi et al., 2014).

The lower carbon content found in both soil layer depths in the rubber tree planting areas compared to that in the forest area (Table 2) may be attributed to the plantation's lower density of trees (500 individuals per hectare), lower diversity of species, and younger age, together with factors such as temperature and humidity within the plantation, as reflected in the lower litter stock (Table 1). This is the principal way in which organic matter is inserted in these plantations.

The carbon content levels in the $0-5-\mathrm{cm}$ topsoil between the two different rubber trees areas were significantly different (Table 2). This was due to the management imposed on natural vegetation in the areas; the area that received two mowings per year (Clone FX 3864) showed the highest carbon content in the $0-10 \mathrm{~cm}$ layer because of the addition of organic matter, as compared with the area that received only one mowing per year (Clone IAN 873).

The areas planted with rubber trees showed higher carbon contents in the topsoil than did the pasture areas $(0-10 \mathrm{~cm})$ (Table 2). These results corroborate those of Portugal et al. (2008) and Maggiotto et al. (2014), who also reported higher carbon stocks in rubber tree plantation areas than in pasture areas. According to those authors, rubber trees have the potential to preserve and/or recover the carbon content, whereas pastures have limited potential for maintaining carbon levels in the soil.

Table 2. Carbon contents in granulometric fractions of soil organic material $\left(\mathrm{g} \mathrm{kg}^{-1}\right)$ and in light fraction organic matter on water in the soil $\left(\mathrm{g} \mathrm{kg}^{-1}\right)$ in various areas.

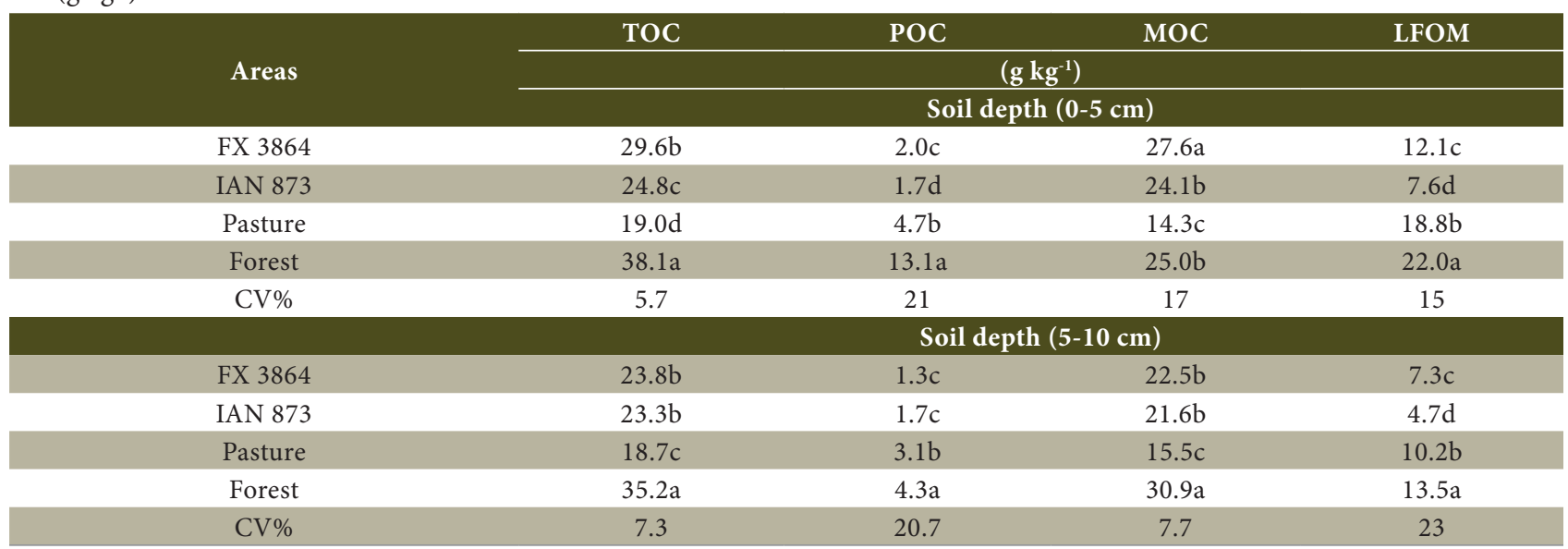

Values followed by the same letter in the column do not differ according to Tukey's test at 5\% probability. TOC: total organic carbon; POC: particulate organic carbon; MOC: mineral-associated organic carbon; LFOM: light fraction organic matter; CV\%: coefficient of variation. 
The lower carbon content found in the pasture areas may be influenced by their greater litter $\mathrm{C} / \mathrm{N}$ ratio (Table 1 ), which prevents rapid decomposition of plant residues and thereby prevents increases in the soil carbon content, resulting in more time being required for changes to take place in carbon contents and stocks. The lower carbon content in the pasture area demonstrates the negative impact on soil when a forest is converted into a pasture, which can lead to less nutrient cycling in the pasture areas than in forest areas (wild forest and rubber tree plantations).

The granulometric fractions of organic matter and LFOM on water showed statistically significant differences between the areas evaluated (Table 2).

The highest levels of LFOM $(0-10 \mathrm{~cm})$ were found in the forest area, followed by the pasture area and then the rubber tree clone areas (Table 2). The higher LFOM content resulted from differences in the supply of litter among the areas (Table 1), allowing greater input of organic matter for the decomposition process that yields LFOM.

The forest and pasture areas showed $81 \%$ and $55.3 \%$ higher LFOM values, respectively, than those for the FX 3864 clone area (Table 2). Relative to the IAN 873 clone area, the LFOM values of the forest and pasture areas were $188 \%$ and $147 \%$ higher, respectively (Table 2). However, the $\mathrm{C} / \mathrm{N}$ ratio of the pasture litter decreased its LFOM decomposition rate relative to that of the rubber tree clone areas. Differences in management between the two areas of rubber tree clones resulted in different LFOM levels, with that of the FX 3864 clone being $59.2 \%$ higher than that of the IAN 873 clone. In their evaluation of 20-year-old rubber tree plantations and areas of a secondary forest, Portugal et al. (2008) also reported lower LFOM levels in the rubber tree plantations $\left(2.55 \mathrm{~g} \mathrm{~kg}^{-1}\right)$ than in the forest $\left(6.90 \mathrm{~g} \mathrm{~kg}^{-1}\right)$, thus corroborating the results of our study.

Regarding the POC content, both soil depth layers (0-5 and $5-10 \mathrm{~cm}$ ) showed the highest levels for the forest area, followed by the pasture area and then the rubber tree plantation areas (Table 2). These results could be explained by the close relationship between the litter stock and LFOM results, since these variables help to create and/or form part of the POC. Thus, it can be said that as compared with the rubber tree areas, the higher POC levels of the forest and pasture areas are related to the higher organic residues that these areas receive. Some studies (Diniz et al., 2015; Guareschi et al., 2012) have also used the relationship between these variables to explain the higher POC contribution of these systems.

The MOC data reflected the previous discussion of the TOC data, in that the rubber trees areas have a greater potential for accumulating carbon than do the pasture areas. This is because, besides having greater levels of MOC $(0-10 \mathrm{~cm})$, they also presented higher levels of this fraction as compared with the vegetation in topsoil that was used as a reference (Table 2).

In the forest area, the POC and MOC in the $0-5-\mathrm{cm}$ layer represented $34.4 \%$ and $65.6 \%$ of the TOC, respectively. In the 5-10-cm layer, the percentage of POC and MOC in the TOC was $12.2 \%$ and $87.6 \%$, respectively. In the pasture area, the POC and MOC corresponded to $24.7 \%$ and $75.3 \%$ of the TOC in the $0-5-\mathrm{cm}$ layer, and $16.5 \%$ and $83.5 \%$ of the TOC in the 5-10-cm layer, respectively. In the area planted with the IAN 873 clone, the POC and MOC respectively accounted for $6.8 \%$ and $93.2 \%$ of the TOC in the $0-5-\mathrm{cm}$ layer, and $7.2 \%$ and $92.8 \%$ of the TOC in the $5-10-\mathrm{cm}$ layer. In the area where the FX 3864 clone was planted, the $0-5-\mathrm{cm}$ layer had POC and MOC levels amounting to $6.7 \%$ and $93.3 \%$ of TOC, whereas the respective $5-10$ $\mathrm{cm}$ layer contents were $5.5 \%$ and $95.5 \%$ of the TOC. The higher MOC levels in relation to POC in these areas were associated with the process of granulometric fraction formation, of which there is a negative correlation; that is, for there to be a higher MOC content in the soil, more decomposition of the POC content is necessary, for later association with soil minerals in the clay and silt fractions (Figueiredo et al., 2010).

Owing to it having a larger supply of litter and LFOM, the forest area presented the highest carbon contents of the humic fractions. Similar to the TOC content, granulometric fractions, and LFOM, different management practices occurring in the two rubber tree clonal plantations resulted in differences in the carbon contents of the humic fractions in the two layer depths evaluated (Table 3).

In all areas evaluated, the humin fraction predominated in relation to the humic acid and fulvic acid fractions (Table 3). These results are corroborated by the studies of Portugal et al. (2008), Fontana et al. (2010), Pegoraro et al. (2011), Pessoa et al. (2012), and Diniz et al. (2015), which also reported the prevalence of carbon in the humin fraction as compared with other fractions in soils from forest species plantations. The high levels of carbon in humin in relation to the other two humic fractions are related to the size of the molecules and their greater stability (Fontana et al., 2010). According to that author, the fulvic acid and humic acid fractions, with their comparatively lower stability, can be translocated to deeper layers, or they can be mineralized or polymerized, thus decreasing their residual content in the soil. 
Table 3. Carbon contents of the humic fractions of organic matter in the soil according to different land uses.

\begin{tabular}{|c|c|c|c|c|c|c|}
\hline \multirow{4}{*}{ Area } & \multicolumn{6}{|c|}{ Carbon in humic fractions } \\
\hline & TOC & C-HS & C-HUM & C-HAF & C-FAF & C-HAF/C-FAF \\
\hline & \multicolumn{6}{|c|}{$\left(\mathrm{g} \mathrm{kg}^{-1}\right)$} \\
\hline & \multicolumn{6}{|c|}{ Soil depth $(0-5 \mathrm{~cm})$} \\
\hline FX 3864 & $29.6 b$ & $22.0 \mathrm{~b}$ & $14.8 \mathrm{~b}$ & $3.8 \mathrm{~b}$ & $3.4 \mathrm{~b}$ & $1.2 \mathrm{~b}$ \\
\hline IAN 873 & $24.8 \mathrm{c}$ & $18.5 c$ & $12.0 \mathrm{c}$ & $3.0 \mathrm{c}$ & $3.5 b$ & $0.90 c$ \\
\hline Pasture & $19.0 \mathrm{~d}$ & $15.7 \mathrm{~d}$ & $11.9 \mathrm{c}$ & $2.0 \mathrm{c}$ & $1.8 \mathrm{c}$ & $1.1 \mathrm{~b}$ \\
\hline Forest & $38.1 \mathrm{a}$ & $31.1 \mathrm{a}$ & $19.3 \mathrm{a}$ & $6.9 \mathrm{a}$ & $4.9 \mathrm{a}$ & $1.4 \mathrm{a}$ \\
\hline \multirow[t]{2}{*}{ CV\% } & 5.7 & 13.6 & 19.0 & 27.4 & 18.4 & 9.8 \\
\hline & \multicolumn{6}{|c|}{ Soil depth $(5-10 \mathrm{~cm})$} \\
\hline FX 3864 & $23.8 \mathrm{~b}$ & $17.8 \mathrm{~b}$ & $11.1 \mathrm{a}$ & $3.7 \mathrm{a}$ & $3.0 \mathrm{~b}$ & $1.2 \mathrm{a}$ \\
\hline IAN 873 & $23.3 b$ & $16.2 b$ & $10.1 \mathrm{~b}$ & $3.3 \mathrm{~b}$ & $2.8 \mathrm{c}$ & $1.2 \mathrm{a}$ \\
\hline Pasture & $18.7 \mathrm{c}$ & $12.3 \mathrm{~b}$ & $8.9 b$ & $1.7 \mathrm{~b}$ & $1.7 \mathrm{~d}$ & $1.0 \mathrm{~b}$ \\
\hline Forest & $35.2 \mathrm{a}$ & $20 \mathrm{a}$ & $12.6 \mathrm{a}$ & $3.7 \mathrm{a}$ & $3.7 \mathrm{a}$ & $1.0 \mathrm{~b}$ \\
\hline CV\% & 7.3 & 15.5 & 19.3 & 22.7 & 8.6 & 13.0 \\
\hline
\end{tabular}

Values followed by the same letter in the column do not differ according to Tukey's test at 5\% probability. C-HS: carbon from humic substances; C-HUM: carbon from the humin fraction; C-FAF: carbon from the fulvic acid fraction; C-HAF: carbon from the humic acid fraction; C-HAF/C-FAF: relationship between the carbon contents of humic acid and fulvic acid; CV\%: coefficient of variation.

In the surface soil layer $(0-5 \mathrm{~cm})$, higher C-HUM, C-FAF, and C-HAF contents were observed for the forest area than for the other areas evaluated (Table 3). These results relate to the larger supply of litter on the forest soil, which favors the humification of organic matter and contributes to increase C-HUM. Similarly, Portugal et al. (2008) reported higher levels of humic substances in the surface layer of the forest area than in that of the rubber tree plantations and pasture.

Furthermore, higher levels of C-HUM, C-FAF, and C-HAF were observed in both the superficial $(0-5 \mathrm{~cm})$ and deeper $(5-10 \mathrm{~cm})$ soil layers of the FX 3864 clone area than in the pasture area (Table 3). Despite its larger litter stock (3.4 Mg ha $^{-1}$ ) (Table 1) and higher LFOM levels (18.8 $\mathrm{g} \mathrm{kg}^{-1}$ ) (Table 2) than those found in both the FX 3864 and IAN 873 clone areas, the pasture area showed lower levels of C-HUM and C-HAF at both soil depths (Table 3). This finding can be explained by the higher $\mathrm{C} / \mathrm{N}$ ratio of the pasture litter (Table 1), which yields a longer lasting material, hindering the action of decomposition agents and slowing the humification process, therefore resulting in a lower C-HUM content. This pattern was also evidenced in the work of Portugal et al. (2008), in which the pasture area showed lower levels of humic substances relative to that of a rubber tree plantation area. According to Kuzyakov \& Domanski (2000), plant residues with higher concentrations of lignin and aromatic compounds (higher $\mathrm{C} / \mathrm{N}$ ratios) have slower decomposition rates.

It is also important to note the similarities in C-HUM and C-HAF contents for the FX 3864 clone and forest areas at the $5-10-\mathrm{cm}$ layer (Table 3 ). These values show the potential of this system to recover or maintain soil carbon.
In their study of the dynamics of these fractions in areas with different rubber tree clones, Diniz et al. (2015) found that the potential to alter the humic substances in the soil under rubber tree cultivation is related to the quantity and quality of organic material that is contributed to the soil. Thus, in areas where there is a greater supply of carbon to the roots and shoots and smaller $\mathrm{C} / \mathrm{N}$ ratio, there is greater C-FAF formation, whereas longer lasting fractions, such as C-HAF and C-HUM, predominate in areas with clones that generate organic residues with higher $\mathrm{C} / \mathrm{N}$ ratio.

Between the two rubber tree clone areas, the differences in the number of mowings and the way in which they were performed caused differences in the C-HUM and C-HAF. The FX 3864 clone area, mowed two to three times a year, had greater C-HUM content than did the IAN 873 clone area that received only one mowing in its planting row (Table 3). The effect of management on these rubber tree plantation areas resulted in the C-HUM and C-HAF contents in the $0-5-\mathrm{cm}$ layer of the FX 3864 clone area, being $23.3 \%$ and $26.6 \%$ greater, respectively, than those of the IAN 873 clone area, whereas the 5-10-cm layer had values corresponding to a 9.9\% increase for C-HUM and a $12 \%$ increase for C-HAF. A larger number of mowings accelerates and facilitates the mineralization of organic matter present therein, which may influence the dynamics of the humic fractions.

Table 3 shows the highest C-HAF/C-FAF ratios of the 0-5$\mathrm{cm}$ layer in the forest area, followed by the FX 3864 clone area and then the pasture area, with the IAN 873 clone area having the lowest value. These results demonstrate the forest and FX 3864 rubber clone areas have a better balance of C-HAF 
and C-FAF formation in the soil, whereas in the IAN 873 clone area, the formation of C-FAF predominated over that of C-HAF. This lower ratio at the surface layer in the area of the IAN 873 clone is explained by the greater levels of C-FAF rather than by the low values of humic acids. Studies in the literature have also identified a greater tendency for C-FAF formation in rubber tree areas (Diniz et al., 2015; Portugal et al., 2008), which may also be related to differences in the area of the clone used when the rubber tree plantation was established (Diniz et al., 2015).

For the 5-10-cm layer depth, the two rubber tree clone areas presented greater C-HAF/C-FAF values than those found for the forest and pasture areas. However, the values are close to 1 , which shows that this layer is experiencing a more balanced formation of C-HAF and C-FAF, forming a material of better quality. The C-HAF/C-FAF ratio is an indicator of the quality of the humus, expressing the degree of evolution of the humification of organic matter.

\section{CONCLUSIONS}

The difference in management of the rubber tree clone area promoted improvements in the soil quality, as it increased the carbon contents of the granulometric fractions, LFOM, and humic substances relative to those of the IAN 873 clone area. Both rubber tree areas evaluated presented higher mineralassociated organic carbon levels and humic substances than did the pasture area, reinforcing the reforestation potential of areas with degraded pastures through hevea culture.

The rubber tree clone areas assessed showed better levels of MOC and humic substances than did the pasture area, which reinforces the potential for reforestation of degraded pasture areas through rubber tree cultivation.

\section{ACKNOWLEDGEMENTS}

This study was financed in part by the Coordenação de Aperfeiçoamento de Pessoal de Nível Superior (Capes).

\section{SUBMISSION STATUS}

Received: 14 Nov. 2017

Accepted: 4 Feb. 2019

Associate editor: João Vicente de Figueiredo Latorraca

(D) 0000-0002-5969-5199

\section{CORRESPONDENCE TO}

\section{Marcos Gervasio Pereira}

Universidade Federal Rural do Rio de Janeiro (UFRRJ),

Rodovia BR 465, km 7, CEP 23890-000, Seropédica, RJ, Brasil

e-mail: mgervasiopereira01@gmail.com

\section{FINANCIAL SUPPORT}

This study was financed by the Coordenação de Aperfeiçoamento de Pessoal de Nível Superior (Capes - Finance Code 001) and Fundação Carlos Chagas Filho de Amparo à Pesquisa do Estado do Rio de Janeiro (Faperj - Award Number: E26/010.001974/2014).

\section{REFERENCES}

Anderson JM, Ingram JSI. Tropical soil biology and fertility: a handbook of methods. Wallingford: CAB International; 1989. $221 \mathrm{p}$.

Barreto RF, Maruyama WI, Bardiviesso DM, Rodrigues TS, Seraguzi EF, Barbosa AV. Adubação de porta-enxertos de seringueira em viveiro suspenso. Revista Floresta 2016; 46(1): 1-9. 10.5380/ rf.v46i1.33885

Benites VM, Madari B, Machado PLOA. Extração e fracionamento quantitativo de substâncias húmicas do solo: um procedimento simplificado de baixo custo. Rio de Janeiro: Embrapa Solos; 2003. p. 1-7. (Comunicado Técnico, 16).

Cambardella CA, Elliott ET. Particulate soil organic-matter changes across a grassland cultivation sequence. Soil Science Society of America Journal 1992; 56(3): 777-783. 10.2136/ sssaj1992.03615995005600030017x

Cotta MK, Jacovine LAG, Paiva HN, Soares CPB, Virgens Filho AC, Valverde SR. Biomass quantification and emission reduction certificates for rubber - cocoa intercropping. Revista Árvore 2008; 32(6): 969-978. 10.1590/S0100-67622008000600002

De Blécourt M, Brumme R, Xu J, Corre MD, Veldkamp E. Soil carbon stocks decrease following conversion of secondary forests to rubber (Hevea brasiliensis) plantations. PLoS One 2013; 8(7): 1-10. 10.1371/journal.pone.0069357

Diniz AR, Pereira MG, Balieiro FC, Silva EV, Santos FM, Oliveira $\mathrm{AB}$ et al. Frações da matéria orgânica do solo em plantios clonais de seringueira em regiões costeiras do Brasil. Revista de la Facultad de Agronomía 2015; 114(1): 106-114.

Fernandes TJG, Soares CPB, Jacovine LAG, Alvarenga AP. Quantificação do carbono estocado na parte aérea e raízes de Hevea sp., aos 12 anos de idade, na zona da mata mineira. Revista Árvore 2007; 31(4): 657-665. 10.1590/S0100-67622007000400010

Figueiredo CC, Resck DVS, Carneiro MAC. Frações lábeis e estáveis da matéria orgânica do solo sob sistemas de manejo e cerrado nativo. Revista Brasileira de Ciência do Solo 2010; 34(3): 907-916. 10.1590/ S0100-06832010000300032

Fontana A, Brito RJ, Pereira MG, Loss A, Benites VM. Caracterização de substâncias húmicas da camada superficial do solo sob diferentes coberturas vegetais. Magistra 2010; 22(1): 49-56.

Gonçalves ECP, Prado RM, Correia MAR. Fontes de fósforo no crescimento de porta-enxerto de seringueira sob condições de viveiro. Revista Floresta 2010; 40(4): 813-818. 10.5380/rf.v40i4.20332

Guareschi RF, Pereira MG, Perin A. Deposição de resíduos vegetais, matéria orgânica leve, estoques de carbono e nitrogênio e fósforo remanescente sob diferentes sistemas de manejo no Cerrado Goiano. Revista Brasileira de Ciência do Solo 2012; 36(3): 909-920. 10.1590/ S0100-06832012000300021 
Guareschi RF, Pereira MG, Anjos LHC, Menezes CEG, Correia MEF. Atributos químicos e físicos do solo sob pastagem e estádios sucessionais de floresta estacional. Revista de la Facultad de Agronomia 2014; 113(1): 1-24.

Kindel A, Carmo CAFS, Lima JAS, Simões B, Alvarenga AP, Pérez DV. Ciclagem de nutrientes e estoque de carbono na serapilheira de seringais e fragmentos da Mata Atlântica. In: Alvarenga AP, Carmo CAFS. Sequestro de carbono: quantificação em seringais de cultivo e na vegetação natural. Viçosa: Epamig. Rio de Janeiro: Embrapa Solos; 2006. p. 135-158.

Kuzyakov Y, Domanski G. Carbon input by plants into the soil. Journal Plant Nutrition and Soil Science 2000; 163(4): 421-431. 10.1002/1522-2624(200008)163:4<421::AID-JPLN421>3.0.CO;2-R

Maggiotto SR, Oliveira D, Marur CJ, Stivari SMS, Leclerc M, WagnerRiddle C. Potential carbon sequestration in rubber tree plantation in the northwestern region of the Paraná State, Brazil. Acta Scientiarum Agronomy 2014; 36(2): 239-245. 10.4025/actasciagron.v36i2.17404

Murbach MR, Boaretto AE, Muraoka T, Souza ECA. Nutrient cycling in a RRIM 600 clone rubber plantation. Scientia Agricola 2003; 60(2): 353-357. 10.1590/S0103-90162003000200021

Pegoraro RF, Silva IR, Novais RF, Barros NF, Fonseca S, Dambroz CS. Estoques de carbono e nitrogênio nas frações da matéria orgânica em Argissolo sob eucalipto e pastagem. Ciência Florestal 2011; 21(2): 261-273. 10.5902/198050983230

Perin A, Santos RHS, Urquiaga S, Guerra JGM, Cecon PR. Produção de fitomassa, acúmulo de nutrientes e fixação biológica de nitrogênio por adubos verdes em cultivo isolado e consorciado. Pesquisa Agropecuária Brasileira 2004; 39(1): 35-40. 10.1590/S0100204X2004000100005

Pessoa PMA, Duda GP, Barros RB, Freire MBGS, Nascimento CWA, Correa MM. Frações de carbono orgânico de um latossolo húmico sob diferentes usos no agreste brasileiro. Revista Brasileira de Ciência do Solo 2012; 36(1): 97-104. 10.1590/S0100-06832012000100011
Portugal AF, Jucksch I, Schaefer CEGR, Wendling B. Determinação de estoques totais de carbono e nitrogênio e suas frações em sistemas agrícolas implantados em Argissolo Vermelho-Amarelo. Revista Brasileira de Ciência do Solo 2008; 32(5): 2091-2100. 10.1590/ S0100-06832008000500030

Rangel OJP, Silva CA, Guimarães PTG, Guilherme LRG. Frações oxidáveis do carbono orgânico de Latossolo cultivado com cafeeiro em diferentes espaçamentos de plantio. Ciência e Agrotecnologia 2008; 32(2): 429-437. 10.1590/S1413-70542008000200013

Rodrigues VA, Costa PN. Análise de diferentes de substratos no crescimento de mudas de seringueira. Revista Científica Eletrônica de Engenharia Florestal 2009; 3(14): 8-17.

Salgado GM. Estoque de carbono orgânico do solo em sistemas agroflorestais com seringueira no sul do estado da Bahia, Brasil [thesis]. Campos dos Goytacazes: Universidade Estadual do Norte Fluminense Darcy Ribeiro; 2016.

Santos LL, Lacerda JJJ, Zinn YL. Partição de substâncias húmicas em solos brasileiros. Revista Brasileira de Ciência do Solo 2013; 37(4): 955-968. 10.1590/S0100-06832013000400013

Siqueira Neto M, Piccolo MC, Costa C Jr, Cerri CC, Bernoux M. Emissão de gases do efeito estufa em diferentes usos da terra no bioma Cerrado. Revista Brasileira de Ciência do Solo 2011; 35(1): 63-76. 10.1590/S0100-06832011000100006

Wauters JB, Coudert S, Grallien E, Jonard M, Ponette Q. Carbon stock in rubber tree plantations in Western Ghana and Mato Grosso (Brazil). Forest Ecology and Management 2008; 255(7): 2347-2361. 10.1016/j.foreco.2007.12.038

Yeomans JC, Bremner JM. A rapid and precise method for routine determination of organic carbon in soil. Communications in Soil Science and Plant Analysis 1988; 19(13): 1467-1476. 10.1080/00103628809368027 